\title{
PROJETOS PARA ESCRITÓRIOS DE ATENDIMENTO AO PÚBLICO BASEADOS EM ANÁLISES ERGONÔMICAS DE AMBIENTES
}

\section{DESIGN FOR PUBLIC SERVICE OFFICES BASED ON ERGONOMICS ENVIRONMENTAL ANALYSIS.}

\author{
Ana Paula Lima Costa ${ }^{1}$, Dra. \\ Vilma Villarouco ${ }^{2}$, Dra. \\ (1) Ministério da Economia \\ aplimacosta@gmail.com \\ (2) Universidade Federal de Pernambuco \\ villarouco@hotmail.com
}

\begin{abstract}
Metodologia de projeto, Serviço público, Ergonomia organizacional
$\mathrm{Na}$ intenção de proporcionar um ambiente de trabalho adequado aos usuários de postos de atendimento ao publico, foram realizadas análises ergonômicas nos ambientes construídos em três repartições públicas brasileiras, usando tres metodologias distintas. Baseados nos resultados foram elaboradas recomendações para a reformulação de cada ambiente e o dimensionamento dos postos de trabalho. Foram evidenciadas as particularidades de cada metodologia.
\end{abstract}

Project methodology, Public service, Organizational ergonomics

To provide adequancy to users in working posts, ergonomic analyzes were performed in three Brazilian public officesBased on results, recommendations for reformulate this environments, adjust and resize the workstations were obtainned. The mainly characteristics of each ergonomic methodology used to design for built environments were highlighted.

\section{INTRODUÇÃO}

O atendimento em repartições públicas é considerado um serviço essencial para a população, contudo, na maioria dos casos, nota-se o despreparo dos seus ambientes para a realização desta atividade.

Preocupados com a melhor adequação dos espaços de trabalho, dirigentes de três repartições públicas solicitaram projetos para reformas e ajustes dos seus ambientes de atendimento ao público, sendo então realizadas avaliações ergonômicas no intuito de verificar as condições de uso de cada um desses locais.

A partir dos resultados com diagnósticos e recomendações, foram elaborados projetos para proporcionar ambientes de trabalho adequados aos usuários, tanto para os atendentes quanto para $\mathrm{o}$ público atendido.

Partindo da premissa que o espaço construído age "como organismo vivo que interage, conduz, viabiliza, abriga, aquece e conforta quem o utiliza" (Villarouco, 2008), este estudo ressalta o ambiente como meio de realização das atividades nele desenvolvidas.

Neste sentido, ao adequá-lo às necessidades do usuário do espaço e às atividades a serem desenvolvidas, o trabalho de atendimento passa a contribuir positivamente para a empresa, para a saúde dos trabalhadores e para o bem estar de todos, promovendo o equilíbrio de todo o sistema.

Segundo Santos e Fialho (1997), uma situação de trabalho é simultaneamente um local onde ocorrem fenômenos sociais e tecnológicos, exigindo que a ergonomia se comporte como ciência social, biológica e exata. Segundo os autores, a análise ergonômica deve considerar estas três áreas de conhecimento cientifico em sua abordagem analítica, adotando os procedimentos de pesquisa, de definição de um quadro teórico de referência, na análise ergonômica da situação de trabalho e na síntese ergonômica desta situação.

Partindo do princípio que as metodologias de avaliação ergonômica abordam a relação entre o indivíduo e seu ambiente de acordo com as 
condições existentes e as finalidades do estudo, foram utilizadas três metodologias que revelassem aspectos importantes de formas distintas.

Com isso, visa-se contribuir na escolha do uso das ferramentas de diferentes metodologias ergonômicas, de modo a identificar a que melhor se adequa ao estudo proposto, tendo em vista que cada metodologia empregada possibilita, de forma diversa, a identificação de fatores relevantes para a investigação ergonômica.

\section{O ESPAÇO DAS EMPRESAS}

As organizações são estruturadas a partir de padrões de autoridade, da divisão do trabalho, dos métodos de controle, das formas de comunicação interna, entre outros aspectos. A cultura organizacional é específica e típica de cada organização, cujos traços são condicionados pelas características culturais da sociedade onde a organização está inserida (Cardoso e Cunha, 2005). Fleury at al aput Schein (1989) cita que a cultura de uma organização pode ser apreendida por diferentes níveis, tais como os artefatos visíveis, o comportamento das pessoas, os valores aparentes e os valores em uso, e os pressupostos básicos que determinam como os membros percebem, pensam e sentem, padronizando os paradigmas culturais.

Segundo Bins Ely (2003), em um ambiente de trabalho, além dos aspectos organizacionais, os aspectos ambientais, tais como a concepção espacial dos ambientes, o leiaute e o conforto ambiental, são importantes ferramentas para melhorar as condições do desenvolvimento das atividades. Como as necessidades funcionais dos usuários estão diretamente relacionadas com as exigências da tarefa, para que o ambiente atenda estas exigências, deve-se considerar a dimensão e o formato do espaço, os fluxos de circulação e a disposição do mobiliário, além do conforto térmico, lumínico e acústico.

A concepção do posto de trabalho deve seguir às características das tarefas realizadas e suas interrelações, pois condições físicas e organizacionais adversas podem dificultar a obtenção de um ambiente agradável, da execução do trabalho de maneira segura e saudável e ter um impacto negativo sobre a produtividade do trabalho. Sommer (1973) afirma que quando as condições são desfavoráveis, a pessoa trabalha mais para compensar suas dificuldades.
As necessidades estéticas ou formais dos usuários estão diretamente ligadas às sensações provocadas pelo ambiente e relacionadas com as preferências ou valores dos indivíduos, dependendo de sua história pessoal, de seu contexto sócio cultural. Van de Voordt (2009) atenta para o aspecto psicológico que ambiente de trabalho proporciona, devendo ser agradável e inspirador.

\section{METODOLOGIA}

Segundo Villarouco (2008), muitas são as variáveis envolvidas na identificação do desempenho adequado de um ambiente construído, o que torna complexa a tarefa de aferir tal adequação, notadamente quando a encaramos sob o enfoque da ergonomia.

Atendendo a demandas de realizar melhorias nos ambientes de atendimento ao público, foram realizadas analises ergonômicas nos ambientes construídos de três repartições públicas brasileiras, denominadas Posto de atendimento A, Posto de atendimento $\mathrm{B}$ e Posto de atendimento $\mathrm{C}$.

Como ferramenta metodológica, foram utilizadas abordagens sistêmicas para a compreensão e identificação dos fatores envolvidos nas atividades humanas no ambiente construído. As metodologias ergonômicas adotadas foram a Análise Macro Ergonômica- AMT (GUIMARÃES, 2006) para o ambiente A, a abordagem do Sistema HumanoTarefa-Máquina - SHTM (MORAES e MONT'ALVÃO, 2003) para o ambiente B e a Metodologia Ergonômica de Avaliação do Espaço Construído - MEAC (VILLAROUCO, 2009) para o ambiente C. As análises ergonômicas e suas recomendações orientaram a elaboração dos projetos arquitetônicos para reforma e adequação dos respectivos espaços físicos das centrais de atendimento avaliadas.

Utilizando três diferentes metodologias, procurou-se aumentar o campo de investigação ergonômica, tendo em vista que as ferramentas identificam aspectos diversos durante as pesquisas, que poderiam vir a se complementarem no entendimento geral dos ambientes de atendimento ao público. 


\section{RESULTADOS DAS ANÁLISES ERGONÔMICAS}

\subsection{Posto de Atendimento A}

O Posto de atendimento A tinha como tarefa orientar o público, receber documentação e alterar dados online. No local trabalhavam 54 servidores públicos, que atendiam cerca de 660 pessoas. $O$ espaço ocupava uma área de $645,25 \mathrm{~m}^{2}$ distribuída em salas de atendimento (Figura 1), sala de espera (Figura 2), e salas de apoio administrativo.

A metodologia de analise ergonômica aplicada foi a Análise Macro Ergonômica do Trabalho - AMT (Guimarães, 2006), método de ação ergonômica com abordagem participativa que focaliza o ser humano, o processo de trabalho, a organização, o ambiente e a máquina como um todo de um sistema mais amplo.

Neste método, os trabalhadores são envolvidos nas decisões sobre seus trabalhos e atividades e são encorajados a tomar decisões em nível organizacional, envolvendo-se efetivamente na organização.

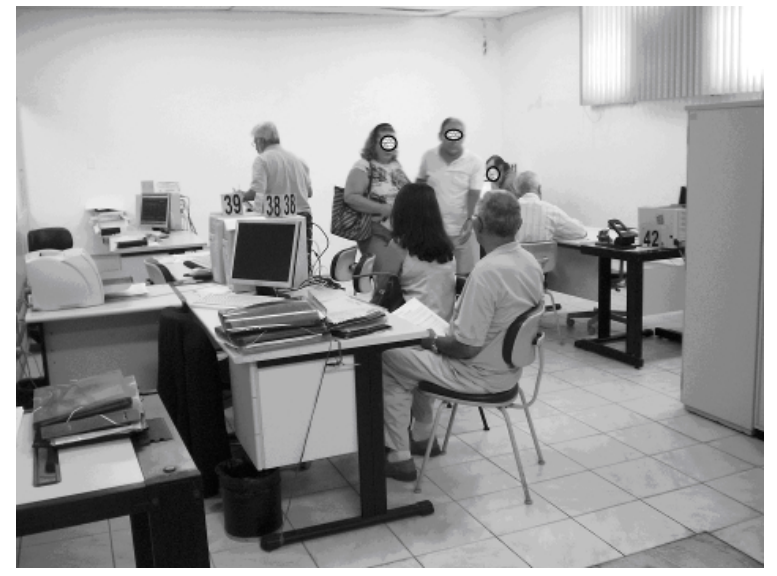

Figura 1 - Sala de atendimento. Fonte: autoras

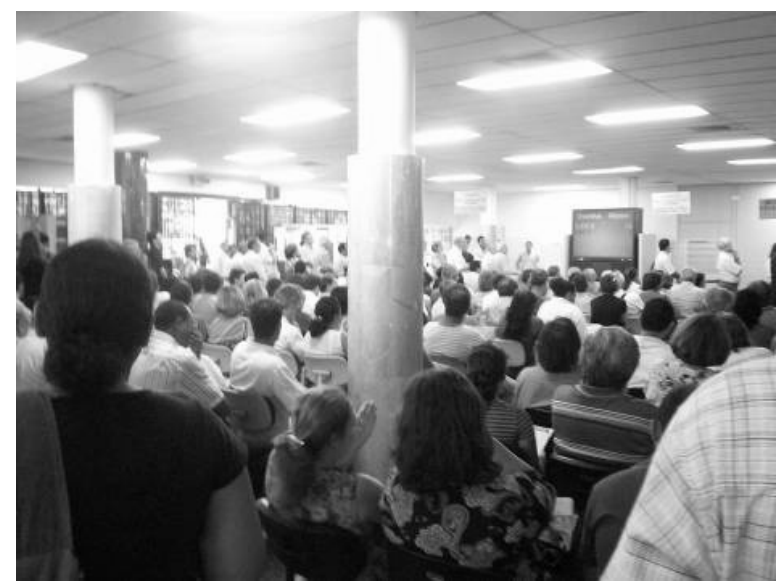

Figura 2 - Sala de espera. Fonte: autoras
A intervenção ergonômica utiliza-se de instrumentos provenientes da ciência e da tecnologia, utilizados de acordo como os fatos são observados pelo pesquisador.

Segundo Iida, (2005), a AMT pode ser definida como o desenvolvimento e aplicação da tecnologia da interface homem-máquina no nível macro, ou seja, em toda organização que abriga a atividade, no qual a ergonomia passa a participar do projeto e gerenciamento de ações, atuando na direção da empresa, refletindo no nível de emprego, qualificação, organização da produção e realização de investimentos, podendo resultar em melhorias de maior alcance do que em abordagem micro, ou seja, no posto de trabalho. Na AMT, são considerados os subsistemas de sistema sociotécnico: o subsistema social (humano), o técnico (tecnológico), o do projeto do trabalho (organização do trabalho) e o relacionado ao ambiente externo (GUIMARÃES, 1999).

Desta forma, a AMT enfatiza a interação entre os contextos organizacional e psicossocial de um sistema, com vistas à melhor adequação de processos e concepção de novos sistemas. Dentre os métodos adaptados para implantação da ergonomia, o processo participativo é um dos mais importantes, no qual o envolvimento dos indivíduos reduz a margem de erros de concepção e garante que o novo sistema implantado tenha melhor aceitação por parte dos trabalhadores (GUIMARÃES, 2004).

A AMT é implementada em seis etapas: lançamento do projeto, levantamento das condições de ambiente físico, do posto de trabalho, dos fatores organizacionais e de conteúdo do trabalho. Com base na discussão dos dados levantados na fase de apreciação, são priorizados os problemas a serem aprofundados e é definido o cronograma de intervenção. Procede-se, então, à fase de diagnóstico, onde as questões priorizadas são analisadas em mais detalhe e são elaboradas proposição de soluções. A última fase de intervenção é a validação, quando são verificadas as modificações propostas. Quando as proposições são aprovadas pelo Comitê de Ergonomia e trabalhadores, é emitido um relatório final de detalhamento de projeto (GUIMARÃES, 1999).

Neste trabalho foram adotadas quatro etapas principais: levantamento inicial das necessidades, projeto da estrutura organizacional e intervenção, implantação do processo e mensuração e avaliação 
da efetividade organizacional.

\subsubsection{Levantamento Inicial das Necessidades}

Nesta fase foram realizadas entrevistas não estruturadas com os funcionários, nos quais eles falavam livremente sobre seu trabalho. As respostas foram tabuladas de forma que os aspectos citados primeiramente e com mais frequência pelos trabalhadores foram considerados como demandas ergonômicas prioritárias.

As demandas foram categorizadas em Ambiente (44\% das respostas), Biomecanica (19\% das respostas), Empresa (18\% das respostas), Organização do trabalho ( $9 \%$ das respostas), Risco do trabalho ( $5 \%$ das respostas), e clientes (5\% das respostas).

Em relação a categoria ambiente, as demandas consideradas prioritárias foram: mobiliário sem espaço suficiente para acomodar os equipamentos e materiais de trabalho, solicitação para melhorar o leiaute do ambiente, percepção de ruído excessivo do ambiente produzido pelos outros atendentes e pelas máquinas de refrigeração, e iluminação do ambiente irregular.

Em relação a categoria biomecânica, as demandas que receberam maior pontuação foram: ocorrência de lesões corporais causadas pelas posturas em mobiliário inadequado, e estresse mental devido ao serviço considerado desgastante pelos entrevistados.
Em relação a categoria empresa, os atendentes reconheciam que seu trabalho era importante para a empresa, mas que suas reivindicações por melhorias de condições de trabalho não eram atendidas pela administração.

Em relação a categoria organização do trabalho, os entrevistados opinaram por uma descentralização do serviço, e que consideravam que o número de atendentes que trabalhavam no local era insuficiente para realizar o serviço satisfatoriamente.

Em relação a categoria de risco de trabalho, foi relatada a agressividade do público para com os atendentes, e a ocorrência de agressões verbais e corporais aos fornecimento de informações sobre o funcionamento da repartição.

Em relação a categoria clientes, foram citados os cuidados que deveriam ser dispensados ao público, tais como fornecimento de informações sobre $o$ funcionamento da repartição.

\subsubsection{Fase de Projeto da Estrutura Organizacional e Intervenção}

Tendo em vista que a finalidade da avaliação ergonômica seria elaborar um projeto arquitetônico para o ambiente, as informações coletadas foram traduzidas em ações ergonômicas direcionadas ao espaço arquitetônico. 


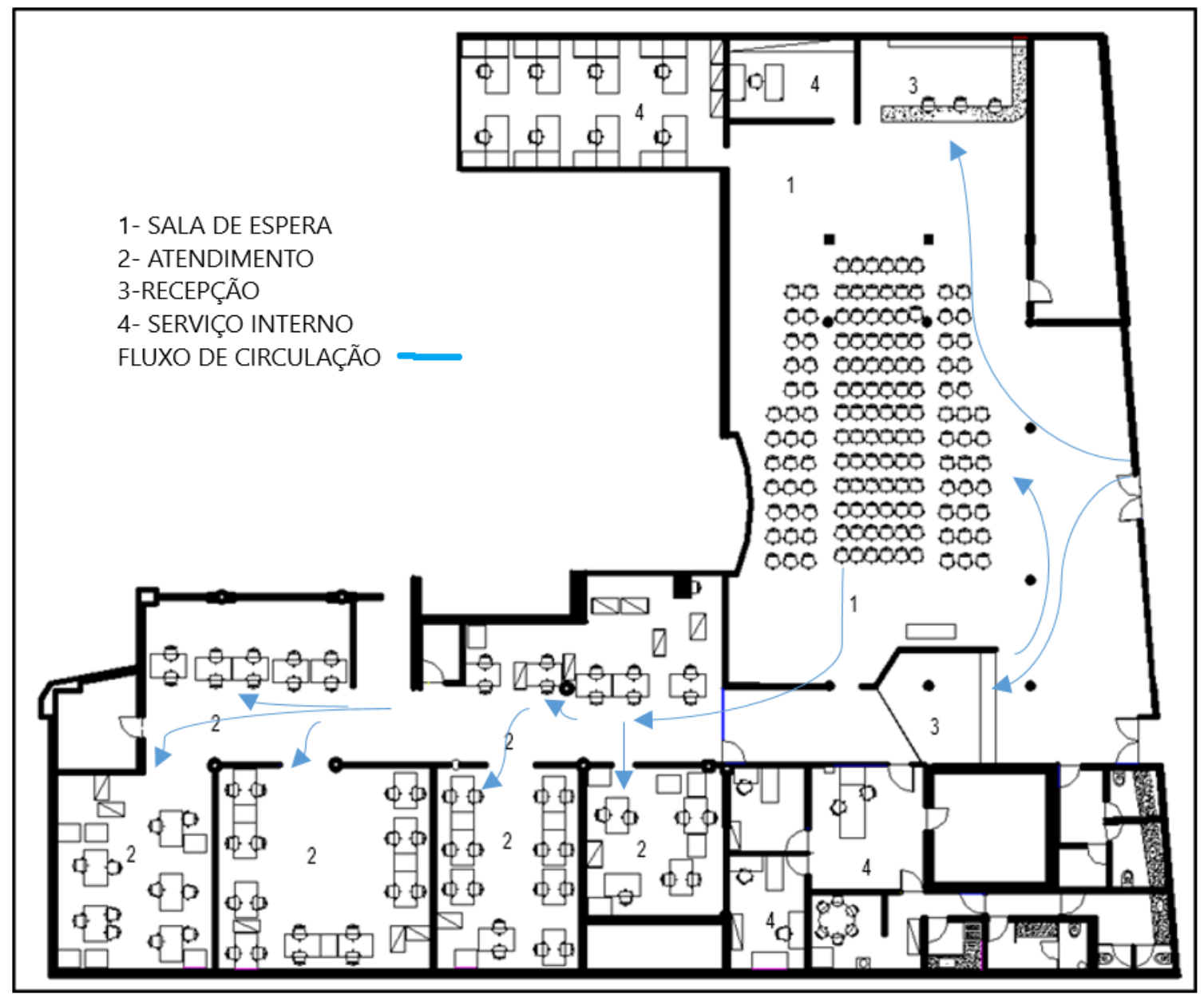

Figura 3. Planta baixa de leiaute do posto de atendimento A. Fonte: autoras

As demais demandas que não se enquadravam nesse aspecto foram apresentadas aos dirigentes da instituição, no intuito de fundamentar um conjunto de ações que viriam a fortalecer as mudanças no ambiente físico.

O projeto de reforma do ambiente construído seguiu a diretriz principal de padronizar os espaços de trabalho, que se apresentavam fragmentados, o que dificultavam o atendimento, segundo o depoimento dos usuários (Figura 3).

Dentre as ações ergonômicas consideradas, as seguintes diretrizes nortearam o projeto arquitetônico: padronização dos ambientes, agrupamento dos postos de trabalho em grupos de atendimento, dimensionamento das estações de trabalho de maneira a acomodar confortavelmente o atendente, seu material e o publico.

Foi projetado um novo sistema de sinalização interna, de modo a orientar o deslocamento do publico externo dentro do ambiente.

Os sistemas de refrigeração e iluminação foram requalificados de modo a serem mais eficientes. As estações de trabalho passaram a ter septos verticais que restringiriam a passagem de ruído de um posto de atendimento para outro. O ambiente deverá receber recursos acústicos de modo a minimizar os incômodos causados pelos ruídos.

As diretrizes foram acomodadas no projeto de reforma, que posteriormente foi executado, trazendo à realidade os elementos observados na análise ergonômica realizada.

A fim de minimizar os incômodos causados pelos ruídos, septos verticais entre as estações de trabalho foram utilizados como recurso acústico, para restringir a passagem de ruído de um posto de atendimento para outro.

Os sistemas de refrigeração e iluminação foram 
requalificados de modo a serem mais eficientes. Foi projetado um novo sistema de sinalização interna para orientar o deslocamento do público externo dentro do ambiente.
Os setores de atendimento foram unificados em um salão único, centralizando o serviço e facilitando o encaminhamento do público. Apenas as áreas de serviço interno ficaram com salas fechadas (Figura 4).

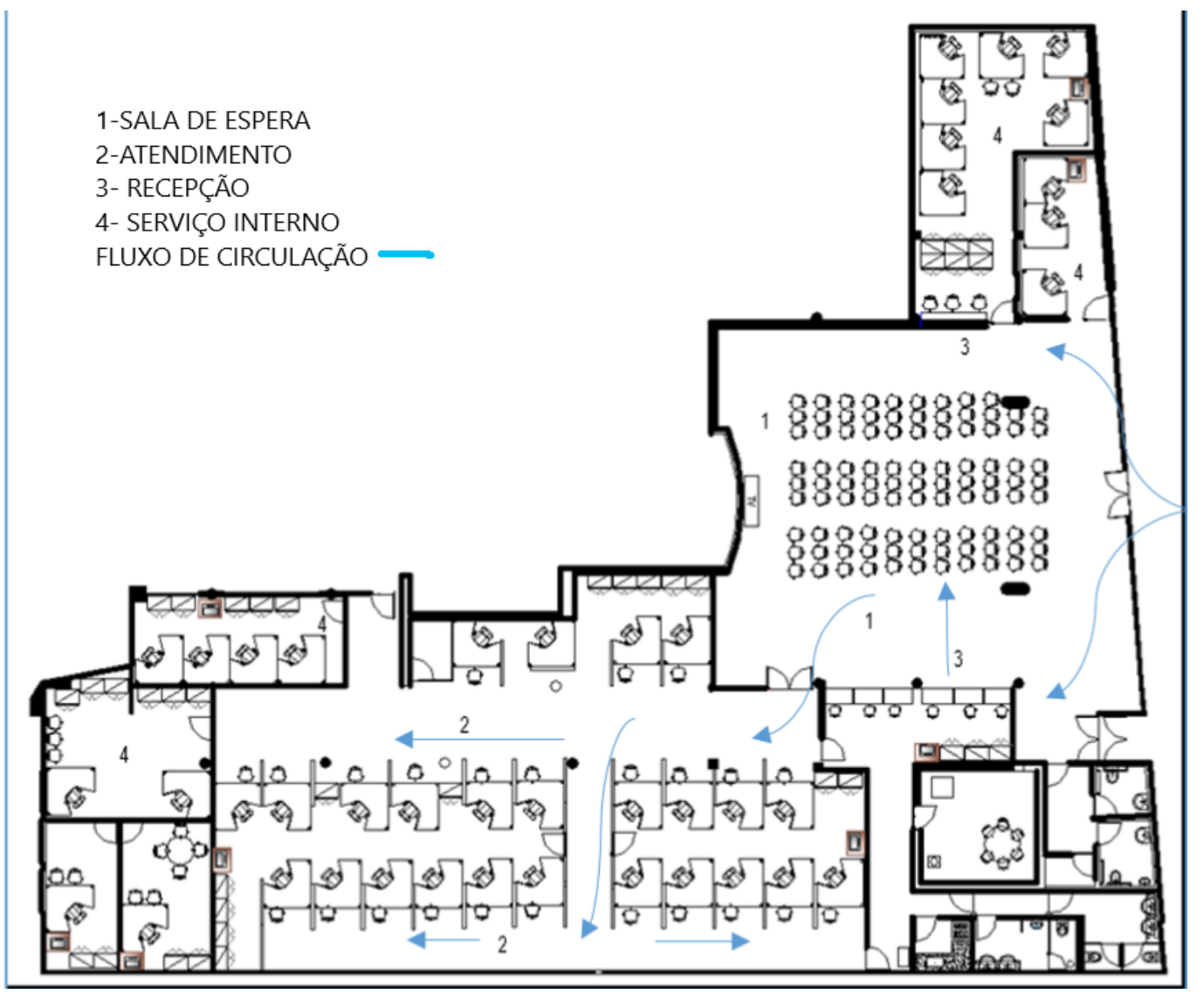

Figura 4. Planta baixa de proposta de leiaute para o posto de atendimento A. Fonte: autoras

\subsubsection{Fase de implantação do processo}

O projeto arquitetônico foi debatido com os dirigentes da instituição e com os chefes dos setores de atendimento. A obra de reforma do ambiente físico foi realizada e foi adquirido o mobiliário dentro das especificações ergonômicas.

Em relação às medidas organizacionais, foi implantado o sistema de marcação prévia do atendimento, fazendo com que o público apenas se deslocasse à repartição pública na hora determinada. Também foram implantados postos de autoatendimento.

\subsection{Posto De Atendimento B}

O Posto de atendimento B recebia diariamente cerca de 80 cidadãos e ocupava uma área de $72,00 \mathrm{~m}^{2}$.

Possuia em seu quadro funcional seis funcionários, que tinham como competência executar as atividades de protocolo e de arquivo, encaminhar a documentação e correspondência recebida e expedida pela Unidade Administrativa.

O ambiente construído do posto de atendimento B foi analisado ergonomicamente utilizando a abordagem do Sistema Humano-Tarefa-Máquina SHTM (Moraes \& Mont'Alvão, 2003).

A conceituação de sistema adotado na sistemática humano-tarefa-máquina enfatiza o desempenho humano definido em termos do todo organizado, observando o enfoque centrado na pessoa, que controla o sistema. Desta forma, para que o sistema seja efetivo, ele deve ser projetado a partir do ponto de vista do operador.

Moraes e Mont'Alvão (2003) construíram o Sistema Humano-Tarefa-Máquina - SHTM, modelo sistêmico expansionista, comportamental e informacional cujo enfoque é centrado na pessoa. 
PUC-Rio Pontifícia Universidade Católica do Rio de Janeiro Departamento de Artes \& Design | PPGDesign

No SHTM, o processamento da informação é baseado em habilidades; as atividades da tarefa agem como expressão da interação entre os dispositivos de informação; o expansionismo do modelo sofre as influências do ambiente físico e organizacional, e a eficiência ergonômica privilegia a economia do homem através da minimização dos custos humanos do trabalho.

Através da abordagem se reconhece o problema e o sistema Humano-Tarefa-Maquina, chegando-se à diagnose ergonômica com as recomendações ergonômicas. A intervenção se divide em cinco etapas: apreciação, diagnose, projetação, validação e detalhamento ergonômico.

Neste estudo, a metodologia foi aplicada até a fase de projetação.

\subsubsection{Apreciação ergonômica}

$\mathrm{Na}$ apreciação ergonômica foi realizado o mapeamento e delimitação dos problemas ergonômicos físico-ambientais, movimentacionais e informacionais. Foram realizadas observações no local e entrevistas. Os problemas foram hierarquizados a partir dos custos humanos do trabalho.

\subsubsection{Diagnose ergonômica}

$\mathrm{Na}$ diagnose ergonômica foram realizadas observações sistemáticas das atividades da tarefa em situação real de trabalho.

Os problemas categorizados foram: Os postos de trabalho não ofereciam acomodações confortáveis ao público que era atendido, não possuíam espaço suficiente para acomodar adequadamente os equipamentos e papéis. Não havia local para guarda de material de uso pessoal dos atendentes (Figuras 5 e 6).

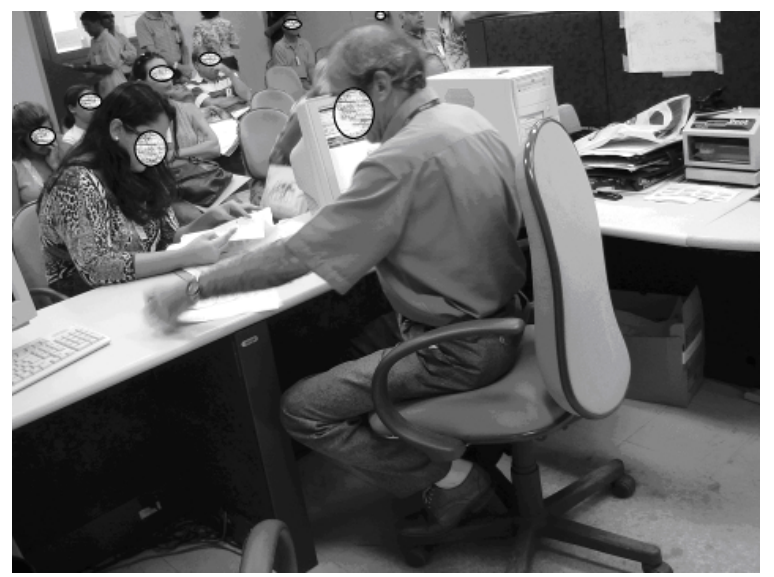

Figura 5- Posto de trabalho
A análise físico-ambiental apontou que os níveis de ruído estavam acima do aceitável e a iluminância média estava abaixo da recomendada pelas normas reguladoras.

Foram identificados como fontes de ruídos: as pessoas que permaneciam na sala de espera, os atendentes, as máquinas protocolizadoras e os aparelhos de refrigeração. A partir dos parâmetros estabelecidos pela NR-17 (BRASIL, 1978), foi constatado que os níveis de ruído $65 \mathrm{~dB}$ (A) a $73 \mathrm{~dB}$ (A) medidos no local, estavam acima do nível aceitável para efeito de conforto de até $65 \mathrm{~dB}$. De acordo com a Tabela 1 da NBR 10152, esses índices encontrados estavam também acima do nível de ruído ambiente, que seria de $45-55 \mathrm{~dB}$ para escritórios de atividades diversas.

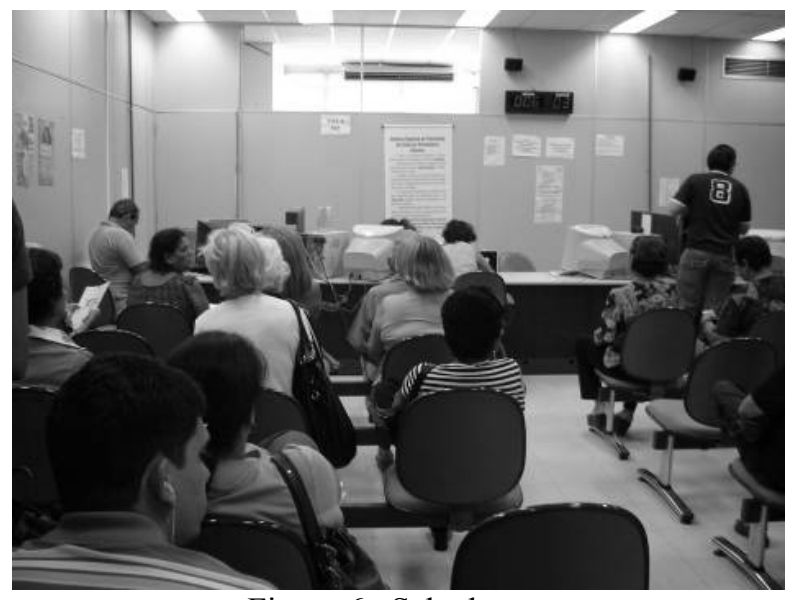

Figura 6-Sala de espera

A iluminância média encontrada no local foi de 454,15 lux, sendo encontrados valores de 95 lux, estando abaixo do determinado pela NBR 5382 (1992) - Iluminância de Interiores, classificado como classe B - Iluminação geral para área de trabalho, temos os valores: $500-700-1000$, para tarefas com requisitos normais, trabalho médio de maquinaria e escritórios.

A temperatura media de $23^{\circ} \mathrm{C}$ encontra-se em condição de conforto, de acordo com a NR-17 (BRASIL, 1978).

O leiaute de distribuição de serviços e de mobiliário não seguia o fluxograma do serviço. Não havia sinalização que orientasse o usuário que deveria pegar uma ficha específica e esperar o chamado.

As demandas ergonômicas identificadas foram: elevado ruído ambiente, falta de sinalização, espaço insuficiente, falta de organização de fila do 
atendimento, área de trabalho insuficiente para movimentação e disposição de equipamentos, inexistência de local para guarda de objetos de uso pessoal.

\subsubsection{Projetação ergonômica}

A partir da planta de leiaute do ambiente, foram identificados os diversos ambientes que compunham o local de atendimento (Figura 7).

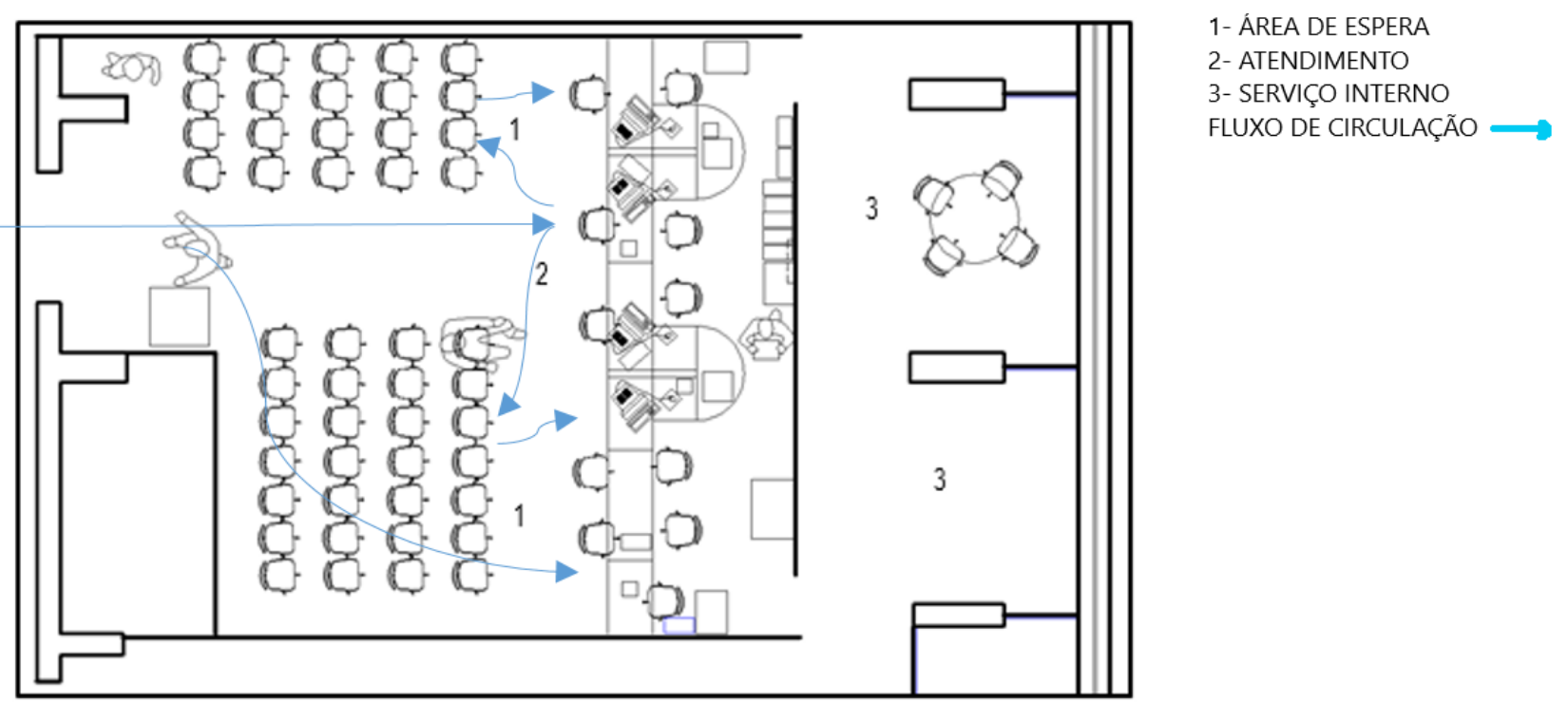

Figura 7. Planta baixa de leiaute do Posto de atendimento B

Na projetação ergonômica o espaço foi adaptado às características físicas e cognitivas dos usuários, através de um projeto de reforma do ambiente, que teve como referencial a distinção de espaços de espera e de atendimento (Figura 8).

A distribuição dos ambientes teve como balizador o fluxograma do público em atendimento, de acordo com as diversas etapas de procedimentos no local: recepção com prestação de informações sobre os serviços prestados e procedimentos de atendimento, entrega de fichas de atendimento, local de espera e sala de atendimento.

$\mathrm{O}$ isolamento entre a sala de espera e sala de atendimento por divisórias buscou restringir o ruído ambiente de cada sala. 


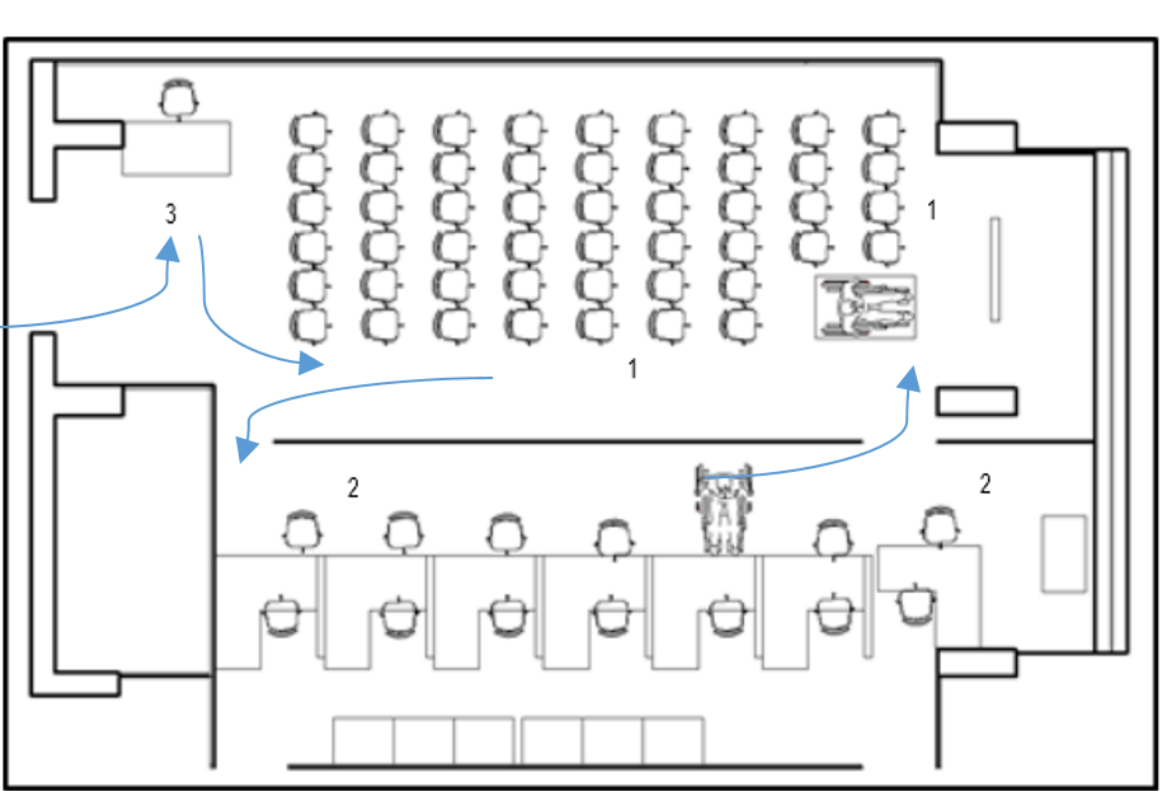

Figura 8. Planta baixa de proposta ergonômica para o Posto de atendimento B

Foram indicados septos entre os postos de trabalho para isolamento físico e acústico. Foram colocadas bancadas de apoio para colocação de material de uso pessoal e documentação em tramitação.

Foi realizado projeto de sinalização interna de modo a atender as necessidades de informação e orientação do ambiente.

\subsection{Posto de Atendimento C}

O Posto de atendimento C contava com 15 servidores e ocupava $164,00 \mathrm{~m}^{2}$ de área. Tinha como competência prestar informações ao público, recepcionar documentos e formalizar processos administrativos.

A Metodologia Ergonômica para o Ambiente Construído - MEAC (VILLAROUCO, 2009) foi utilizada para a avaliação.

A MEAC analisa o espaço físico conjugando avaliações físico-espaciais à uma ferramentas de identificação da percepção ambiental. Pautada em uma abordagem sistêmica, abrange variáveis das áreas envolvidas no espaço edificado, tendo como elemento primordial o usuário deste espaço e suas percepções ambientais, por ser o elemento que absorve os impactos que o ambiente transmite.

Tomando como ponto de partida o modelo encontrado em Santos e Fialho (1997) da Análise Ergonômica do Trabalho- AET, a Metodologia
Ergonômica para o Ambiente Construído - MEAC proposta por Villarouco $(2008,2009)$ procura estabelecer uma analogia entre as fases da análise tradicional e aquelas necessárias à avaliação do espaço com foco no trabalho nele realizado, verificando possíveis interações prejudiciais à produtividade ou que pudessem proporcionar uma melhoria das condições de trabalho.

Na MEAC, a ferramenta de percepção adotada deve advir da necessidade, sendo a Constelação de Atributos (SCHMIDT, 1974) utilizada neste trabalho na identificação de variáveis da percepção ambiental dos usuários. Os dados físicos obtidos e os perceptuais são cruzados, de modo a obter o diagnóstico ergonômico do ambiente.

A MEAC é compreendida em quatro etapas analíticas: Análise Global do Ambiente, Identificação da Configuração Ambiental, Avaliação do Ambiente em Uso no Desempenho das Atividades e Percepção Ambiental. Após as analises, chega-se ao Diagnóstico Ergonômico do Ambiente e finaliza com as Proposições.

Na fase de análise global do ambiente são colhidas informações sobre o ambiente e as atividades, e na fase de Identificação da Configuração Ambiental verificam-se os condicionantes físico-ambientais, através do levantamento dos dados do ambiente, tais como: dimensionamento, iluminação, ventilação, ruído, temperatura, fluxos, leiaute e condições de acessibilidade, levantando-se as primeiras hipóteses sobre a questão das influências do espaço na 
execução das atividades do trabalho.

A etapa da avaliação do ambiente em uso no desempenho das atividades visa identificar o quanto facilitador ou inibidor o ambiente representa ao desenvolvimento das atividades que abriga. Continua com a fase de Percepção Ambiental onde se identificam as variáveis de caráter mais cognitivo, verificando a percepção que o usuário tem do ambiente.

No diagnóstico ergonômico se obtém o entendimento geral da situação, gerando dados para a fase de proposições de intervenções e soluções das questões que interferem negativamente no desempenho do sistema.

\subsubsection{Análise Global do Ambiente}

A temperatura ambiente era irregular. A sinalização interna estava deficiente. Havia fiação elétrica próxima aos postos de trabalho, causando aos usuários temor de choques elétricos. Não se distinguia que existiam diferentes tipos de atendimento a público com procedimentos distintos (Figuras 9 e 10).

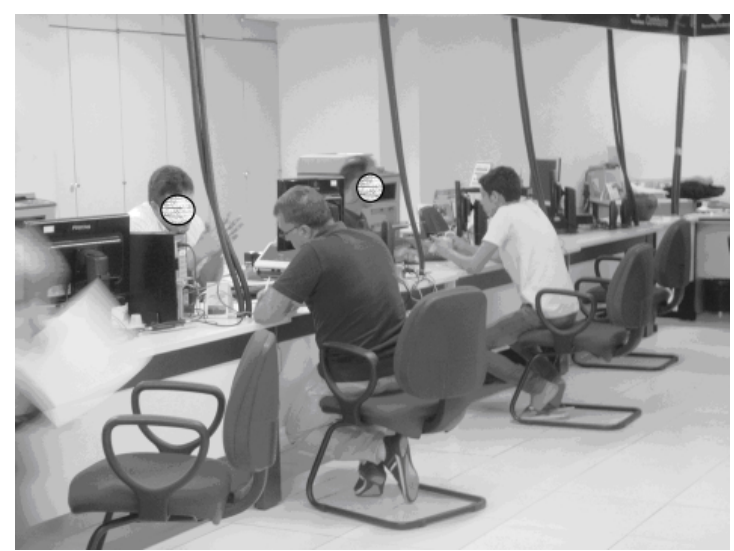

Figura 9 - Postos de atendimento

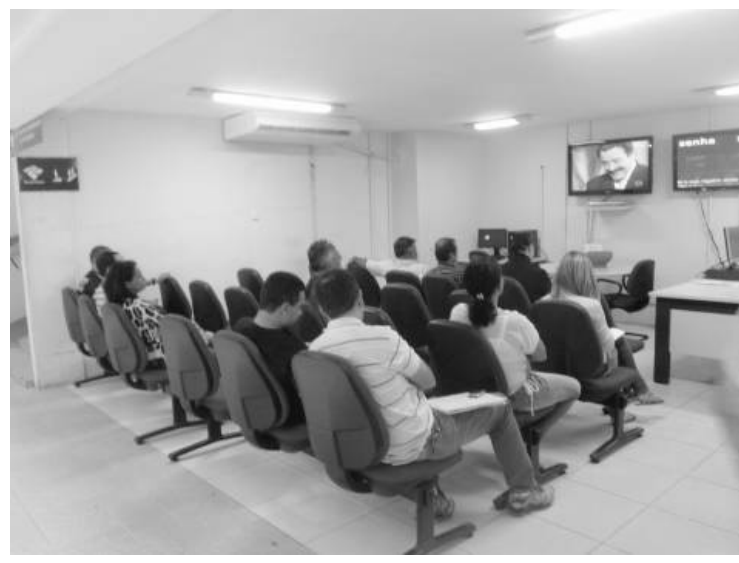

Figura 10 - Sala de recepção e espera

\subsubsection{Identificação da Configuração Ambiental}

A área de atendimento estava dividida em recepção, espera, atendimento e área de uso exclusivo dos trabalhadores. A falta de portas isolando as áreas dificultava o controle de acesso do público (Figura 11).

As condições de iluminação, temperatura e nível de ruído encontravam-se em desacordo com os valores recomendados pelas normas brasileiras NBR 5413 (1992), NR-17(1978) e NBR 10152 (2000), respectivamente. Os postos de trabalho estavam agrupados e tinham o atendimento prejudicado pelo ruído e falta de privacidade. 


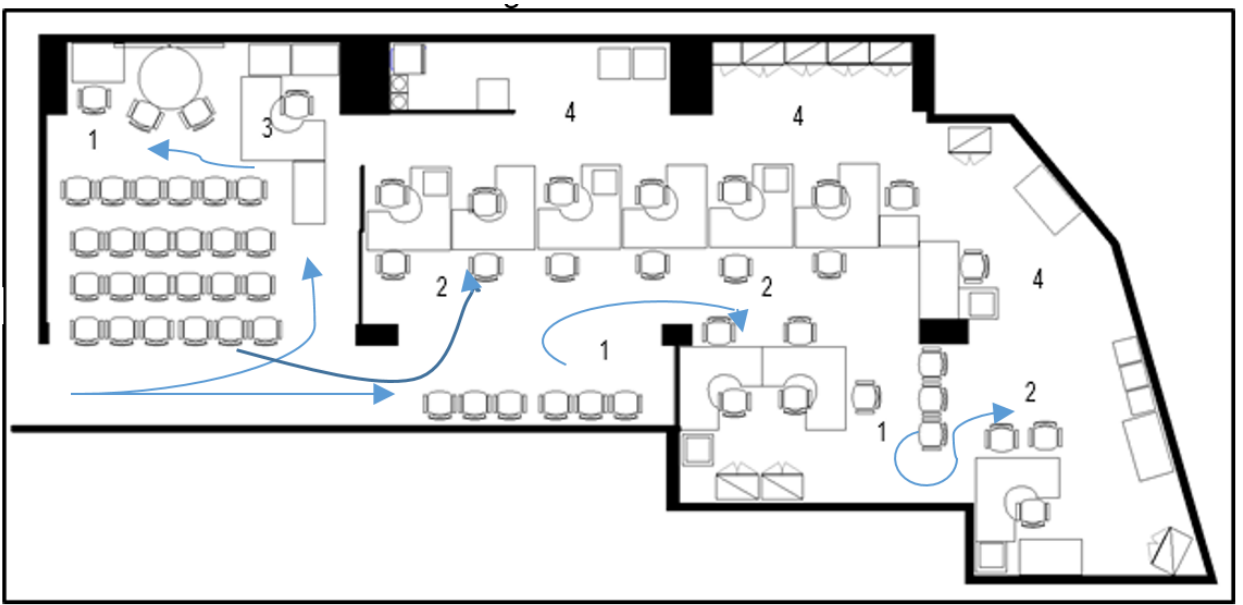

1- ÁREA DE ESPERA 2-ATENDIMENTO

3- RECEPÇÃO

4- SERVICOO INTERNO

FLUXO DE CIRCULAÇÃO $\longrightarrow$

Figura 11. Planta baixa do Posto de atendimento C

As superfícies de trabalho não possuíam profundidade suficiente, proporcionando proximidade excessiva entre o atendente e o público, favorecendo o contágio de doenças

infectocontagiosas e causando constrangimento pela invasão do espaço pessoal (HALL, 1982). A acessibilidade inexistia, dificultando o acesso a pessoas com deficiência, deixando de cumprir a legislação pertinente, o que é incompatível com uma empresa pública.

\subsubsection{Avaliação do Ambiente em uso no Desempenho das Atividades}

Existiam dois locais de espera, sendo que para um dos tipos, o atendimento era direto, e para outro tipo era necessário pegar uma ficha na recepção e aguardar o chamado eletrônico de atendimento na sala de espera. Contudo, a falta de sinalização indicando estes procedimentos fazia com que o público se encaminhassem para o atendimento sem ter sido autorizado, prejudicando os atendimentos que estavam sendo realizados.

\subsubsection{Percepção Ambiental do Usuário}

Na fase de Percepção Ambiental se identifica as variáveis de caráter mais cognitivo, verificando a percepção que o usuário tem do ambiente em duas etapas: primeiramente se questiona a sua idealização de um ambiente de trabalho ideal e depois se questiona as suas impressões sobre o ambiente que ele utiliza, através de uma ferramenta de percepção ambiental, neste caso a Constelação de Atributos (SCHMIDT, 1974).

As respostas em relação ao ambiente ideal mostraram os anseios dos usuários, e as respostas em relação ao ambiente real mostraram os fatores que eles percebiam no ambiente. A conjunção das respostas revelou os fatores que os usuários percebiam no seu ambiente de trabalho.

As respostas dos usuários em relação ao ambiente ideal remeteram a um ambiente confortável, agradável, espaçoso, com uma boa distribuição interna, com boas condições térmicas e lumínicas e com mobiliário que se adequasse ao atendimento ao público. As respostas em relação ao ambiente que os usuários ocupavam revelaram que eles consideram o ambiente inadequado, com refrigeração deficiente, ruidoso, mal distribuído internamente, com falta de controle de entrada e de privacidade.

A avaliação das respostas dos usuários revelou que eles percebiam que o ambiente em que trabalhavam não estava adequado às realizações das suas atividades, e indicavam quais as demandas que seriam prioritárias para eles: melhoria na distribuição interna para melhor controle do fluxo de atendimento, intervenções nas condições ambientais e adequação no mobiliário a fim de melhor acomodar os materiais de trabalho. 


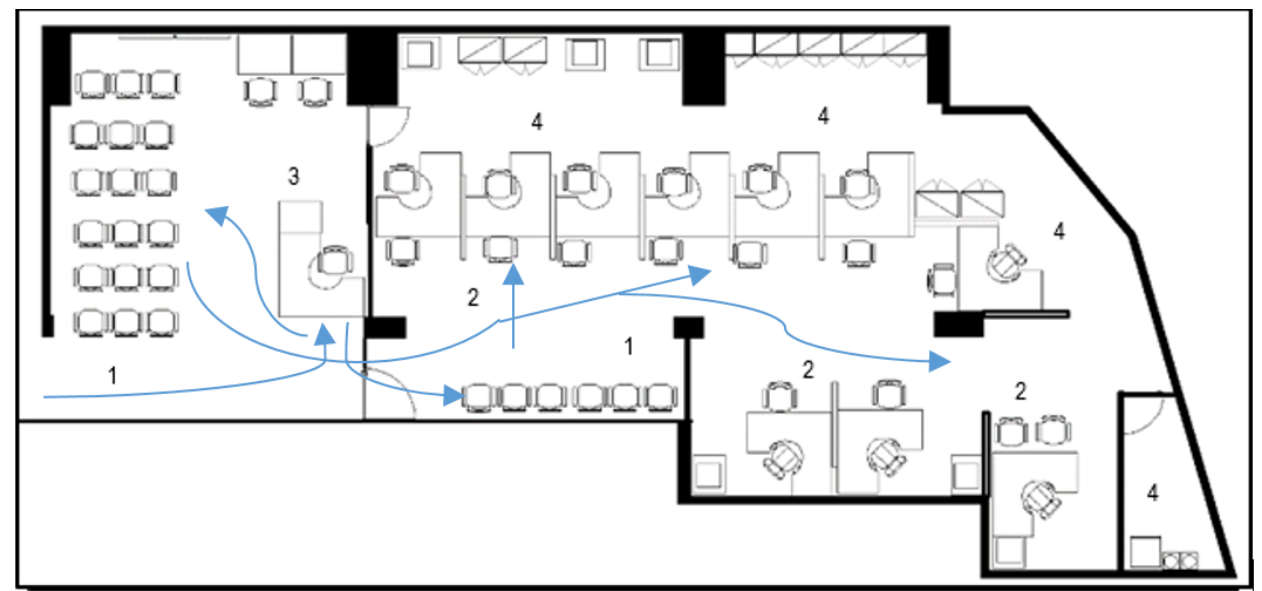

1- SALA DE ESPERA

2- ATENDIMENTO

3- RECEPÇÃO

4- SERVICCO INTERNO

FLUXO DE CIRCULAÇÃO

Figura 12. Planta baixa de proposta ergonômica para o Posto de atendimento

\subsubsection{Diagnóstico Ergonômico do Ambiente}

A partir da identificação da configuração ambiental, da avaliação do ambiente em uso no desempenho das atividades e da percepção ambiental dos usuários obteve-se o diagnóstico ergonômico do ambiente.

As demandas ergonômicas identificadas foram: distribuição dos ambientes inadequada, fluxos de circulação de pessoas e serviços conflitantes, falta de sinalização interna, postos de trabalho com dimensões e configurações inadequadas e falta de atendimento às normas regulatórias das condições físicas do ambiente.

\subsubsection{Proposições Ergonômicas}

O produto final da analise ergonômica são as proposições, expressas em uma lista de recomendações para o projeto para resolver os problemas identificados.

A partir do diagnostico ergonômico, foram elaboradas as proposições ergonômicas, que constituem as recomendações de intervenções no ambiente

Os sistemas de refrigeração e iluminação deveriam ser adequados. As estações de trabalhos deveriam ter dimensões ajustadas para acomodar o atendente, o público e seus materiais. Deveriam ser instalados septos verticais de vidro entre as superfícies de trabalho, de modo a isolar fisicamente e acusticamente cada atendimento.
A sala de atendimento deveria ser isolada da sala de espera por uma porta, de modo a controlar o acesso do público ao local de atendimento e restringir o acesso não autorizado ao local. A distribuição dos postos de trabalho deveria ter como balizador os tipos de atendimento a serem realizados (Figura 12).

Quadro 01 - Resumo de demandas e recomendações $\mathrm{O}$ posto de entrega de fichas de atendimento deveria ser deslocado para junto da porta de entrada. Os serviços semelhantes deveriam ser agrupados de modo a não haver cruzamento de fluxos. A sinalização interna deveria ser executada de modo a orientar a sequencia e as normas de atendimento, bem como informar os serviços prestados no local.

\section{RESULTADOS OBTIDOS}

As demandas ergonômicas relativas aos ambientes físicos foram dispostas juntamente com as respectivas recomendações ergonômicas para cada ambiente (Tabela 01). Apesar de terem sido utilizadas diferentes metodologias ergonômicas, percebeu-se que as demandas e recomendações se assemelhavam e se complementavam. 


\begin{tabular}{|c|c|c|c|}
\hline \multirow[t]{2}{*}{ Demanda ergonômica } & \multicolumn{3}{|c|}{ Recomendação ergonômica } \\
\hline & Ambiente A & Ambiente B & Ambiente C \\
\hline $\begin{array}{l}\text { Mobiliário sem espaço } \\
\text { suficiente para acomodar } \\
\text { os equipamentos e } \\
\text { materiais de trabalho e do } \\
\text { público. }\end{array}$ & $\begin{array}{l}\text { Dimensionar o mobiliário de } \\
\text { maneira a acomodar } \\
\text { confortavelmente o atendente } \\
\text { e o público. }\end{array}$ & $\begin{array}{l}\text { Instalação de bancadas de } \\
\text { apoio para colocação de } \\
\text { material de uso pessoal e } \\
\text { documentação em tramitação. }\end{array}$ & $\begin{array}{l}\text { As estações de trabalhos } \\
\text { deverão ter dimensões } \\
\text { adequadas para acomodar o } \\
\text { atendente, o público e seus } \\
\text { materiais de trabalho. }\end{array}$ \\
\hline $\begin{array}{l}\text { Os postos de trabalho não } \\
\text { acomodam os usuários } \\
\text { com conforto. }\end{array}$ & $\begin{array}{l}\text { Realizar analise ergonômica } \\
\text { para adequar o posto de } \\
\text { trabalho }\end{array}$ & $\begin{array}{l}\text { Realizar analise ergonômica } \\
\text { para adequar o posto de } \\
\text { trabalho }\end{array}$ & $\begin{array}{l}\text { Realizar analise ergonômica } \\
\text { para adequar o posto de } \\
\text { trabalho }\end{array}$ \\
\hline $\begin{array}{l}\text { Distribuição interna do } \\
\text { ambiente (leiaute) } \\
\text { deficiente. }\end{array}$ & $\begin{array}{l}\text { Padronizar os ambientes de } \\
\text { atendimento. }\end{array}$ & $\begin{array}{l}\text { Distinção e isolamento de } \\
\text { espaços de espera e de } \\
\text { atendimento. }\end{array}$ & $\begin{array}{l}\text { A sala de atendimento deve } \\
\text { ser isolada da sala de espera } \\
\text { por uma porta, para controle } \\
\text { do acesso do público ao local } \\
\text { de atendimento e restringir o } \\
\text { acesso não autorizado. }\end{array}$ \\
\hline $\begin{array}{l}\text { Ruído excessivo do } \\
\text { ambiente }\end{array}$ & $\begin{array}{l}\text { As estações de trabalho } \\
\text { passaram a ter septos } \\
\text { verticais que restringiriam a } \\
\text { passagem de ruído de um } \\
\text { posto de atendimento para } \\
\text { outro. }\end{array}$ & $\begin{array}{l}\text { O isolamento entre a sala de } \\
\text { espera e sala de atendimento } \\
\text { por divisórias restringe o ruído } \\
\text { ambiente de cada sala. } \mathrm{Na} \\
\text { sala de atendimento os } \\
\text { postos de trabalho possuem } \\
\text { septos entre si com o intuito } \\
\text { de oferecer isolamento. }\end{array}$ & $\begin{array}{l}\text { Deverá ter septos verticais de } \\
\text { vidro entre as superfícies de } \\
\text { trabalho, de modo a isolar } \\
\text { fisicamente e acusticamente } \\
\text { cada atendimento. }\end{array}$ \\
\hline Iluminação deficiente. & $\begin{array}{l}\text { Redimensionar o sistema de } \\
\text { iluminação }\end{array}$ & $\begin{array}{l}\text { Redimensionar o sistema de } \\
\text { iluminação }\end{array}$ & $\begin{array}{l}\text { O sistema de iluminação deve } \\
\text { ser adequado de modo a } \\
\text { proporcionar condições } \\
\text { ambientais adequadas. }\end{array}$ \\
\hline $\begin{array}{l}\text { Refrigeração } \\
\text { irregular/ruidosa }\end{array}$ & $\begin{array}{l}\text { Redimensionar sistema de } \\
\text { refrigeração. }\end{array}$ & $\begin{array}{l}\text { Adequar o sistema de } \\
\text { refrigeração. }\end{array}$ & $\begin{array}{l}\text { O sistema de refrigeração } \\
\text { deve ser adequado de modo } \\
\text { a proporcionar condições } \\
\text { ambientais adequadas. }\end{array}$ \\
\hline $\begin{array}{l}\text { O leiaute não segue o } \\
\text { fluxograma do serviço. Há } \\
\text { fluxos de circulação } \\
\text { conflitantes entre pessoas e } \\
\text { serviços. }\end{array}$ & $\begin{array}{l}\text { Os postos de trabalho foram } \\
\text { agrupados em três ilhas de } \\
\text { atendimento, reduzindo assim } \\
\text { a dispersão do público. }\end{array}$ & $\begin{array}{l}\text { A distribuição dos ambientes } \\
\text { teve como balizador o } \\
\text { fluxograma do público em } \\
\text { atendimento. }\end{array}$ & $\begin{array}{l}\text { A distribuição dos postos de } \\
\text { trabalho deve ter como } \\
\text { balizador os tipos de } \\
\text { atendimento a serem } \\
\text { realizados Os serviços } \\
\text { semelhantes deverão ser } \\
\text { agrupados de modo a não } \\
\text { haver cruzamento de fluxos } \\
\text { com os atendimentos. }\end{array}$ \\
\hline $\begin{array}{l}\text { Falta de sinalização interna } \\
\text { e informação de serviços. }\end{array}$ & $\begin{array}{l}\text { Foi aplicado um novo sistema } \\
\text { de sinalização interna, de } \\
\text { modo a orientar o } \\
\text { deslocamento do público } \\
\text { externo dentro do ambiente. }\end{array}$ & $\begin{array}{l}\text { Foi realizado projeto de } \\
\text { sinalização interna de modo a } \\
\text { atender as necessidades de } \\
\text { informação e orientação do } \\
\text { ambiente. }\end{array}$ & $\begin{array}{l}\text { A sinalização interna deverá } \\
\text { ser executada de modo a } \\
\text { orientar a sequencia e as } \\
\text { normas de atendimento, bem } \\
\text { como informar os serviços } \\
\text { prestados no local. }\end{array}$ \\
\hline
\end{tabular}

\subsection{Considerações sobre os Resultados Obtidos nas Metodologias}

As informações sobre o ambiente foram colhidas pelas três metodologias de forma estruturada e livre, e as demandas foram sistematizadas baseadas nas respostas dos usuários dos ambientes.

Contudo, na análise AMT, as demandas foram priorizadas pelos resultados das entrevistas, enquanto que nas análises SHTM e MEAC, ocorreu a conjunção dos anseios e queixas dos usuários com o levantamento físico realizado em campo.

Os elementos gerados para elaboração de projeto do ambiente construído na análise AMT originaram-se das informações coletadas em campo, que foram traduzidas em ações ergonômicas direcionadas ao espaço arquitetônico.

Na análise SHTM, os requisitos para realização da tarefa determinados na diagnose ergonômica conceituaram o projeto, considerando a alocação de funções entre o homem e o ambiente.

$\mathrm{Na}$ análise MEAC, o entendimento geral da situação foi obtido a partir da conjugação dos elementos coletados nas análises físicas do ambiente com as impressões dos usuários que geraram dados para as proposições de intervenções. 


\begin{tabular}{|c|c|c|c|}
\hline Merramenta & $\begin{array}{l}\text { Análise Macro Ergonômica- } \\
\text { AMT (GUIMARÃES, 2006) }\end{array}$ & $\begin{array}{l}\text { Sistema Humano-Tarefa- } \\
\text { Máquina - SHTM (MORAES e } \\
\text { MONT'ALVÃO, 2003) }\end{array}$ & $\begin{array}{l}\text { Metodologia Ergonômica para o } \\
\text { Ambiente Construído - MEAC } \\
\text { (VILLAROUCO, 2008, 2009) }\end{array}$ \\
\hline Foco da metodologia & $\begin{array}{l}\text { Tratar dos níveis gerenciais } \\
\text { hierárquicos, da } \\
\text { comunicação e da } \\
\text { organização do trabalho }\end{array}$ & $\begin{array}{l}\text { Abordar o estudo } \\
\text { pormenorizado das atividades } \\
\text { realizadas em situação real de } \\
\text { trabalho }\end{array}$ & $\begin{array}{l}\text { Aprofundar-se nos dados } \\
\text { físicos, funcionais e perceptuais } \\
\text { do ambiente }\end{array}$ \\
\hline $\begin{array}{l}\text { Abordagem dos aspectos } \\
\text { físicos do ambiente }\end{array}$ & $\begin{array}{l}\text { As informações coletadas } \\
\text { nas entrevistas são } \\
\text { traduzidas em demandas } \\
\text { ergonômicas }\end{array}$ & $\begin{array}{l}\text { Análise através de } \\
\text { instrumentos de medição e } \\
\text { métodos normatizados }\end{array}$ & $\begin{array}{l}\text { Levantamento dos dados } \\
\text { através de instrumentos de } \\
\text { medição e utilização de normas. }\end{array}$ \\
\hline $\begin{array}{l}\text { Abordagem dos aspectos } \\
\text { funcionais do ambiente }\end{array}$ & $\begin{array}{l}\text { As informações coletadas } \\
\text { nas entrevistas são } \\
\text { relacionadas à } \\
\text { funcionalidade do ambiente }\end{array}$ & $\begin{array}{l}\text { Observações sistemáticas das } \\
\text { atividades da tarefa em } \\
\text { situação real de trabalho }\end{array}$ & $\begin{array}{l}\text { Verificaram-se os } \\
\text { condicionantes de fluxos, leiaute } \\
\text { e influência na execução das } \\
\text { atividades do trabalho }\end{array}$ \\
\hline $\begin{array}{l}\text { Levantamento das } \\
\text { demandas }\end{array}$ & $\begin{array}{l}\text { Parte de dados coletados } \\
\text { nas entrevistas } \\
\text { desestruturadas }\end{array}$ & $\begin{array}{l}\text { Observações no local, } \\
\text { entrevistas e registros } \\
\text { fotográficos }\end{array}$ & $\begin{array}{l}\text { Através de levantamento dos } \\
\text { dados do ambiente, e } \\
\text { entrevistas com usuários }\end{array}$ \\
\hline Priorização de demandas & $\begin{array}{l}\text { Em entrevista livre os } \\
\text { usuários que externam as } \\
\text { suas percepções do } \\
\text { ambiente. As respostas } \\
\text { mais citadas indicam os } \\
\text { fatores que mais os atingem }\end{array}$ & $\begin{array}{l}\text { Utilização do sistema } \\
\text { participativo de usuário e } \\
\text { levantamento técnico para } \\
\text { quantificar e objetivar a } \\
\text { avaliação de alternativas }\end{array}$ & $\begin{array}{l}\text { Os usuários relatam as suas } \\
\text { percepções do ambiente em } \\
\text { entrevista livre. Conjugam-se } \\
\text { com as análises do ambiente } \\
\text { para que as demandas mais } \\
\text { influentes se evidenciem }\end{array}$ \\
\hline $\begin{array}{l}\text { Elementos gerados para } \\
\text { elaboração de projeto do } \\
\text { ambiente construído }\end{array}$ & $\begin{array}{l}\text { Originaram das informações } \\
\text { coletadas traduzidas em } \\
\text { ações ergonômicas } \\
\text { direcionadas ao espaço } \\
\text { arquitetônico }\end{array}$ & $\begin{array}{l}\text { Os requisitos para realização } \\
\text { da tarefa determinados na } \\
\text { diagnose ergonômica } \\
\text { conceituam o projeto, sendo } \\
\text { considerando a alocação de } \\
\text { funções entre o homem e o } \\
\text { ambiente }\end{array}$ & $\begin{array}{l}\text { No diagnóstico ergonômico se } \\
\text { obtém o entendimento geral da } \\
\text { situação, gerando dados para } \\
\text { proposições de intervenções e } \\
\text { soluções }\end{array}$ \\
\hline
\end{tabular}

Quadro 02 - comparativo do uso das metodologias

Todas as metodologias utilizaram entrevistas e outras ferramentas de interação com os usuários, de modo a colherem informações sobre os trabalhadores, seus anseios e impressões sobre o ambiente.

No primeiro caso, os elementos gerados para elaboração do projeto do ambiente construído são priorizados pelas informações coletadas na AMT, revelando o caráter mais organizacional da ação ergonômica.

$\mathrm{Na}$ análise SHTM os aspectos funcionais entre o homem e o ambiente são evidenciados na investigação, e na MEAC ocorre a validação dos dados coletados no ambiente através da percepção do usuário sobre o seu ambiente.

Em todos os casos é evidenciado o caráter sistêmico do olhar ergonômico sobre os ambientes avaliados, traduzindo-se nas intervenções projetadas.

\subsection{Proposta Para Ocupação de Ambientes Construídos Destinados ao Atendimento ao Público}

A partir das demandas encontradas nas análises ergonômicas realizadas nos Postos de atendimento
A, $\mathrm{B}$ e C, foram elaboradas diretrizes para a configuração e implantação de ambientes de atendimento ao público, listadas a seguir.

- A área destinada ao atendimento ao público deveria ser zoneada a partir de ações necessárias que o público teria que efetuar para ser atendido, tais como ser recepcionado, aguardar ser chamado e receber o atendimento.

- O leiaute do ambiente deveria ter como balizador a sequencia de ações necessárias para efetuar o serviço de atendimento.

- Quando houvesse mais de um tipo de atendimento, os postos de trabalho mais demandados em número de atendimentos deveriam ser localizados em locais mais próximos ao acesso.

- A organização do ambiente físico deveria ter como referencial a distinção de espaços reservados para cada tipo ação necessária para $o$ atendimento.

- As áreas de atendimento e de espera deveriam ser separadas por septos de modo a proporcionar o isolamento visual $\mathrm{e}$ acústico das duas áreas. O acesso ao local de atendimento deveria ser controlável.

- O dimensionamento do posto de trabalho 
deveria obedecer às medidas

antropométricas de modo a contribuir para a definição das relações dimensionais entre o homem e a tarefa por ele realizada. As superfícies de trabalho deveriam ter dimensões suficientes para acomodar os usuários e seus equipamentos e materiais, de modo a não causar constrangimento aos movimentos (SOARES, 2007).

- As estações de trabalho dos atendentes deveriam ser separadas entre si por meio de septos de materiais transparentes, de modo a manter o contato visual entre os atendentes e isolar acusticamente os postos durante o atendimento (Figuras 13 e 14).

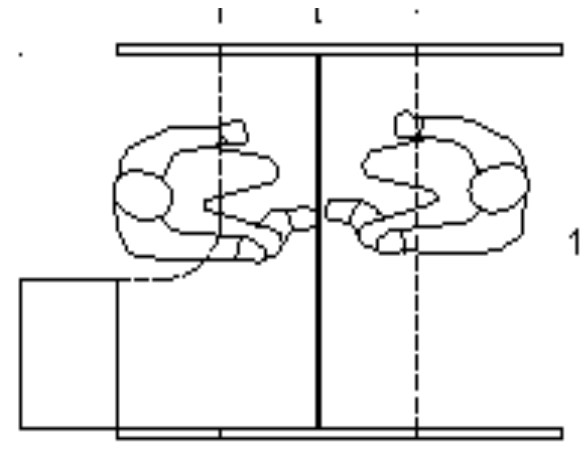

Figura 13-Planta-baixa do posto de trabalho

- As superfícies de trabalho deveriam ter profundidade suficiente para acomodar confortavelmente tanto o atendente como a pessoa a ser atendida. A maior profundidade da mesa também promoveria também um maior distanciamento entre o atendente e o público, preservando, assim, o espaço pessoal dos indivíduos.

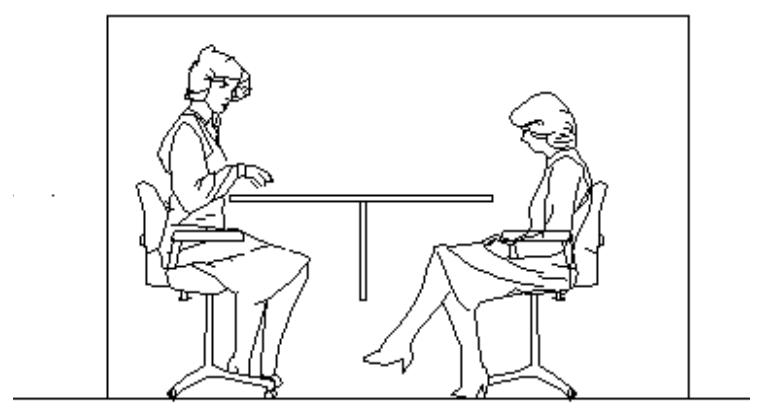

Figura 16-Corte transversal de posto de trabalho

\section{CONCLUSÕES}

Novas formas de conceber e organizar o trabalho muitas vezes requerem novos espaços, nos quais as formas de desenvolvimento das atividades tornam-se aspectos de relevante importância sobre a motivação e a produtividade do trabalhador.

A necessidade de adequar os ambientes construídos às necessidades humanas impõe desafios constantes aos projetistas e predisposição das organizações para a quebra de paradigmas proveniente das concepções impostas pelas convenções organizacionais.

A despeito dos limites enfrentados pela tarefa do atendente, as análises ergonômicas realizadas apontaram como principal demanda a proposta de um novo arranjo físico ao setor. A materialização da solução foi representada em recomendações de ocupação do ambiente, alcançando assim o objetivo desta pesquisa.

As três ferramentas metodológicas utilizadas neste estudo para a compreensão e identificação dos fatores envolvidos nas atividades humanas no ambiente construído, apresentaram aspectos relevantes para a compreensão global da relação entre o usuário e seu ambiente.

Contudo, observa-se que os elementos se complementam nas análises, considerando que os atributos que elas desvendam no decorrer dos estudos, apresentam aspectos relevantes para a compreensão global da relação entre o usuário e seu ambiente.

A partir dos resultados das intervenções observa-se que o tipo de análise a ser realizada no ambiente direciona a escolha do uso de cada metodologia, tendo em vista que a análise AMT direciona-se a investigar as questões envolvendo os níveis hierárquicos administrativos na organização do trabalho, a análise SHTM estuda minuciosamente as atividades em situação real de trabalho, e a MEAC se debruça nos aspectos funcionais, físicos e perceptuais sobre o ambiente.

A oportunidade de utilização de três metodologias distintas, em ambientes de trabalho semelhantes, contribuiu na pesquisa sobre a utilização de metodologias de análises ergonômicas em ambientes construídos, contribuindo na otimização desses espaços, com considerações sobre conforto ambiental, fluxo, acessibilidade e mobiliário.

Assim, recomenda-se que a escolha sobre a utilização da metodologia de investigação ergonômica seja voltada principalmente sobre os 
aspectos que se queira investigar na análise ergonômica, e também seja verificada a ferramenta que mais se adeque às particularidades do ambiente e aos propósitos da investigação

\section{REFERÊNCIAS BIBLIOGRÁFICAS}

ABNT Associação Brasileira De Normas Técnicas - NBR 5382 (1992) - Iluminância de interiores, Rio de Janeiro conforto acústico

BRASIL (1978). Ministério do Trabalho e Emprego - NR-17- Ergonomia (117.000-7).

BINS ELY, Vera Helena Moro. Ergonomia + Arquitetura: buscando um melhor desempenho do ambiente físico. In: Anais do $3^{\circ}$ ERGODESIGN Congresso Internacional de Ergonomia e Usabilidade de Interfaces Humano-Tecnologia: Produtos, Programas, Informação, Ambiente Construído, 2003

CARDOSO, Carmen Maria Mota; CUNHA, Francisco Carneiro da. Parceria Com o Cliente. Modelo de Prática para Consultores e Assessores. 2.ed- Recife. Instituto de Tecnologia em Gestão, 2005.

FLEURY, Maria Teresa Leme; SHINYASHIKI, Gilberto Tadeu; STEVANATO, Luiz Arnaldo. Arqueologia Teórica e Dilemas Metodológicos dos Estudos sobre Cultura Organizacional. Cultura Organizacional e Cultura Brasileira. São Paulo, 1997.

GUIMARÃES, Lia Buarque de Macedo; Costelha, Marcelo Fabiano. Macroergonomia. In: Guimarães, Lia Buarque de Macedo. Ergonomia de Processo, volume 2. Porto Alegre, FEENG/UFRGS, 2006.

Introdução à ergonomia. In: Guimarães, Lia Buarque de Macedo. Ergonomia de Processo, volume 1. Porto Alegre, FEENG/UFRGS. 2004.

Abordagem Ergonômica: o Método

Macro. In: Guimarães, Lia Buarque de Macedo. Ergonomia de Processo, volume 1. Porto Alegre: UFRGS/PPGEP. 1999

HALL, Edward T. (1982). The Hidden Dimension. Anchor Books, New York.
IIDA, Itiro. Ergonomia: projeto e produção. $2^{\mathrm{a}}$ edição - São Paulo: Blucher, 2005

MORAES \& MONT'ALVÃO (2003). Ergonomia Conceitos e Aplicações. $3^{\text {a }}$ Ed. Rio de Janeiro: Ed. iUsEr.

SANTOS, N. dos; FIALHO, Francisco. Manual de Análise Ergonômica do Trabalho. 2. ed. Curitiba, Genesis, 1997.

SCHMIDT, J. L. La percepción del habitat.

Barcelona: Ed. Gustavo Gili, 1974

SCHEIN, E. Organizational culture and leadership. San Francisco: Jossey-Bass, 1989. p. 86

SOARES, Marcelo. Apostila do $5^{\circ}$ Curso de Pósgraduação em Ergonomia. Antropometria. UFPE, 2007.

SOMMER, Robert. Espaço pessoal: as bases comportamentais de projetos e planejamentos. São PAULO, Ed. da Universidade de São Paulo, 1973

VAN DER VOORDT, J. M. Als alles werkt, werkt u beter! De invloed van uw werkomgeving op uw arbeidsproductiviteit. Office Rendement (9) $\mathrm{N}^{\circ} 2$, 2009.

VILLAROUCO, Vilma. An ergonomic look at the work environment. In: Proceedings of the 17th World Congress on Ergonomics, Beijing, China, 2009.

Construindo uma metodologia de avaliação ergonômica do ambiente - AVEA. In: Anais do XV Congresso Brasileiro de Ergonomia ABERGO- Porto Seguro, 2008. 